\title{
Analysis of the Relationship of Biographical Characteristics and Factors of Organizational Climate in the Service Sector of the City of Chihuahua
}

\section{Acosta García Paulina Ivetteㄹ, Martínez Ramos Pedro Javier², Reyes López José Gerardo1, Daniela Yenthile Rodríguez Hernández ${ }^{2}$}

\author{
${ }^{1}$ Facultad de Contaduría y Administración, Universidad Autónoma de Chihuahua, Chihuahua, México \\ ${ }^{2}$ Facultad de Ciencias Químicas, Universidad Autónoma de Chihuahua, Chihuahua, México \\ Email: pauacoatg@gmail.com,pmartinr@uach.mx,jreyes@uach.mx,yhernandez@uach.mx
}

How to cite this paper: Ivette, A. G. P., Javier, M. R. P., Gerardo, R. L. J., \& Hernández, D. Y. R. (2021). Analysis of the Relationship of Biographical Characteristics and Factors of Organizational Climate in the Service Sector of the City of Chihuahua. Open Journal of Business and Management, 9, 2793-2815. https://doi.org/10.4236/ojbm.2021.96156

Received: September 12, 2021

Accepted: November 2, 2021

Published: November 5, 2021

Copyright $\odot 2021$ by author(s) and Scientific Research Publishing Inc. This work is licensed under the Creative Commons Attribution International License (CC BY 4.0).

http://creativecommons.org/licenses/by/4.0/

\begin{abstract}
The organizational climate is a concept that has evolved within the framework of the administration, whose focus is to support men and organizations to create environments in which the various resources are managed, to achieve the objectives and goals. On the other hand, the biographical characteristics are data that are easily defined, since they are obvious factors, but that impact the behavior and perceptions of employees in the workplace. An empirical, applied, non-experimental, cross-sectional investigation, with a quantitative approach, was carried out in the city of Chihuahua, in the period January to December 2019. The objectives were: to diagnose the organizational climate, describe the biographical characteristics of employees and identify the relationship between biographical characteristics and organizational climate factors in the service sector. The research design was descriptive and correlational. The universe of companies was 1108 , the sample size, with a $95 \%$ confidence level and a 10\% margin of error for finite populations, was 90 companies. The biographical characteristics evaluated were age, sex, marital status, department of work, seniority, academic degree, and type of personnel. To assess the organizational climate, a questionnaire of 76 questions, divided into 12 factors, was used as a measurement instrument (Chiang Vega et al., 2007). The information analysis was descriptive and correlational, the statistical tests of Cronbach's Alpha, bivariate correlations, mean K analysis, and the chi-square test was used. The perception of the organizational climate is adequate since most of the results were positive towards the organizational climate factors. Cronbach's Alpha showed a value of 0.929 . The bivariate correlations showed three results with statistical significance. The mean $\mathrm{K}$ analy-
\end{abstract}


sis showed differences and/or response groups in all biographical characteristics. The chi-square analysis identified the type of personnel as the biographical characteristic with the greatest relationship to the factors of the organizational climate. The diagnosis of $\mathrm{OC}$ and the biographical characteristics are very valuable tools since they provide information about the variables and processes that impact the organizational behavior system, this undoubtedly gives a guide to the development of plans and programs, which can be implemented through the human capital management area, to improve behaviors and attitudes and with this, help improve the overall performance of organizations.

\section{Keywords}

Biographical Characteristics, Factors, Organizational Climate, Organizational Behavior, Human Capital Management, Administration

\section{Introduction}

The organizational climate (OC) has its origin in organizational psychology, it is born on the principle that man lives in complex and dynamic environments, since companies are made up of people, groups, and societies, this generates diverse behaviors, which have an impact on the environment, which is perceived by individuals and has an influence on their behavior (García Solarte, 2009; Grueso et al., 2016). At first, the scholars of the subject focused on man and his social relations, as causes of productivity in an organization, this led to the emergence of the Humanistic School of Administration led by Elton Mayo in the United States, a theory that tried to humanize the workplaces and center people as the most important asset for companies, since these were being oriented to the application of organizational methods and practices little oriented to consider human needs (Jojoa Vargas, 2017; Ganga et al., 2015; Arano et al., 2016; Méndez Álvarez, 2006).

The organizational climate is a concept that has evolved within the framework of the administration, whose main focus is to support men and organizations to create environments in which the various resources available are planned, organized, directed, and controlled, to achieve the objectives and goals. Of the resources that a company has, human capital is the most important, it is the people who create the organizational environment, commonly called OC, then some stages of the evolution of the administration are mentioned and how it is built the concept of OC.

The scientific management (late 19th century) represented by Taylor and Fayol, although they did not mention OC as such, the repetitive tasks that characterized this era and the economic rewards implemented to motivate workers, undoubtedly set precedents to generate a productive environment or environment.

The School of Human Relations (1930) was led by Mayo and Hellriegel, among 
others. These theorists began with the application of psychology in companies and to consider the needs of workers. They raised the idea that productivity has a direct relationship with the care and treatment that workers receive (Arano et al., 2016).

The Structuralist school (1950) represented by authors such as Weber, in this stage organizations are identified as social systems, in which dynamic relationships are established that have an impact on behavior and therefore on productivity (Arano et al., 2016).

The Behavioral School (1960) in which theorists such as Skinner, Maslow, Herzberg, and McGregor, proposed among other things that, in the organizational environment, it was very important to manage the consequences that workers obtained for their behavior, in that way it was possible to establish a system of rewards and punishments. At this time, the OC construct was consolidated (Arano et al., 2016; Ehrhart \& Schneider, 2016; Ganga et al., 2015).

By the previous conceptions, the importance of the human subject within organizations should be pointed out, because the perception they have of the environment will determine the commitment they establish for the achievement of the objectives and the contributions they make to increase the efficiency and effectiveness (Ganga et al., 2015; Araque et al., 2018; Balla Carchi \& Vera Sánchez, 2018).

The perception of the environment, that a person has when carrying out their work, the treatment that a boss may have with his subordinates, the relationship between the entity's personnel, and even the relationship with suppliers and users, all these elements make up what we call OC, this can be a link or an obstacle to the good performance of the organization as a whole or of certain people who are inside or outside it, it can be a factor of distinction and influence on the behavior of those who make it up. In short, it is the personal expression of the perception that workers and managers form of the organization to which they belong, and that directly affects the performance of the organization.

In this research work, two relevant aspects are presented that deserve attention: The first of them is the decision-making that is related to the daily interactions that occur between the people who make up this organization, they must be regulated by agreements that respect individual integrity and the organization as such. The second aspect is related to human relations and the achievement of organizational objectives. It is known that an adequate OC is positively related to productivity (Jojoa Vargas, 2017).

The OC diagnosis allows organizations to obtain data, which when analyzed becomes valuable information, to plan actions for continuous improvement, design, or redesign, of organizational structures, strategic planning, changes in the internal organizational environment, management of motivation programs, performance management, improvement of internal and external communication systems, improvement of production processes, improvement in remuneration systems, among others (Sánchez, 2017; Iglesias Armenteros et al., 2018). By the 
aforementioned, the concern was generated to carry out this research, whose objectives were: to describe the biographical characteristics of the personnel working in the service sector of the city of Chihuahua, to prepare a diagnosis of OC in the aforementioned sector, and finally to identify the relationship between biographical characteristics and organizational climate factors.

The main contributions of this research were: to validate an OC diagnostic instrument, another contribution is to enrich the work of other researchers (Robbins et al., 2013; Acosta \& Venegas, 2010), who affirm that the biographical characteristics of the employees impact the perception that employees have of the OC. These two contributions provide valuable data to the area of human capital, with which it is possible to influence the continuous improvement of companies. In the present investigation, some limitations were faced, such as the information of the biographical characteristics is difficult to obtain, since this information is personal and sensitive, another important one was that in the work environments there is little support for the investigation, the collection process Data is difficult and in the case of questionnaires, employees do not want to invest time to answer it.

To achieve the proposed objectives of this research, as well as to try to verify the hypothesis that there is a relationship between biographical characteristics and organizational climate factors, a literary review of the organizational climate variable and the evolution of the same. This activity allowed guiding and sustaining this research. Next, reference is made to the method used to carry out this study. The results of the research are also presented, as well as the discussion or conclusions derived from this research.

\section{Literature Review}

The OC is of primary interest in the business environment since it has a fundamental impact on the management of human resources, the leading role that it has as an object of study is based on the influence it has on organizational processes and psychology, such as communication, decision-making, problem-solving, learning, motivation, as well as their impact on the efficiency of the organization and the satisfaction of its members (Méndez Álvarez, 2006; Villanueva Galicia et al., 2017; Iglesias Armenteros et al., 2020).

OC is a multidimensional variable composed of sub-variables such as organizational structure, size of the organization, modes of communication, and management leadership styles, among others. All these elements make up a particular climate where their characteristics prevail, which, in some way, constitute the personality of an organization. However, the behavior of a worker is not the result of the sub-variables, but of how the worker perceives these factors, these perceptions largely depend on the activities, interactions, and other series of experiences that each member has with the company. Based on the above, it is possible to infer the importance of generating a good organizational climate because it allows increasing productivity, reducing absenteeism, reducing costs, 
and improving performance that allows achieving organizational objectives (Chagray Ameri et al., 2020; Morales Gaviria \& Silva Mercado, 2012; Quintero et al., 2008; Cárdenas Niño et al., 2009).

The OC, in some way, is understood as the environment where people work and find their balance point, to achieve the objectives that they consider valuable, whether or not they coincide with those of the organization. The OC turns out to be an important administrative tool in the decision-making of managers, which allows them to project organizational efficiency, lead the management of changes, and continuous improvement since the survival of organizations falls on this. Therefore, to understand OC it is necessary to understand the behavior of people, the structure of the organization, and the processes that are developed in it (Sagredo Pérez, 2013; Iglesias Armenteros et al., 2018; Chagray Ameri et al., 2020).

OC is an issue investigated by many scholars, who have laid the foundations of a concept of great importance in administrative theory, the foundation of this construct, can be seen in Table 1.

As can be seen in Table 1, the work of consolidating the constructs of Climate and organizational culture has been intense and of great added value for the understanding of the complex and interesting social system in which companies are constituted, these concepts are constituted As perspectives from the same point, the social interactions that occur in the business environment, the demolition of the boundaries that exist between culture and organizational climate, will be the greatest challenge that researchers will face in the years to come.

As the study of organizational climate and culture has grown, it has focused on the impact that these constructs have on organizational effectiveness (Ehrhart et al., 2013). That is why this research aims to contribute to the understanding of the concept of $\mathrm{OC}$ and its diagnosis, however, much work remains to be done as to how the biographical characteristics are related to the perception that employees have of the OC and how it impacts organizational performance.

\section{Method}

This empirical, applied research, with a non-experimental, cross-sectional design (descriptive and correlational) with a quantitative approach, was carried out in the city of Chihuahua, from January to December 2019. Regarding the subjects, the sampling frame to identify the population of 1108 micros ( 0 to 10 employees) and small companies (from 11 to 50 employees), registered in the service sector in the State of Chihuahua and obtain their sample, is based on the records of the National Institute of Statistics and Geografía (INEGI) (INEGI, 2014). The sample size, considering the total number of companies in the city of Chihuahua (1108), with a $95 \%$ confidence level and a $10 \%$ margin of error for finite populations, was 90 companies.

The methodology for data collection was: visit the companies and apply the questionnaire with the help of the human resources department, to employees in the areas of spare parts, units, and workshops. 
Table 1. Some of the theorists have contributed to the concept of Organizational Climate.

First period (before 1970): the pioneers of the social context in organizations

Authors
K. Lewin, R. Lippitt,
R. White.

R. White.

E. Fleishman

Pace \& Stern

year Main contributions

1939

Argyris

Schein

Katz y Kahn

Likert

Schneider y Bartlett

1968 That they applied to assess the climate of life insurance agencies that contained similar dimensions to those proposed by Litwin.

Second period (1971-1985): fundamentals of the definition and measurement of the construct.

At the beginning the debate focused on the following question: if the climate is an attribute of the environment, but is perceived by individuals in the environment, how can it be investigated in the environment? These authors clarified the conceptually calling climate studies at the individual level "psychological climate" and studies in the (organizational) unit.

James y Jones

Schneider

They were the pioneers in making the first approaches to the concept of organizational climate, through conceptions such as social atmosphere, postulating the existence of 6 dimensions that account for the social climate: warmth and support, conformity, responsibility, standards of excellence, rewards, and organizational clarity.

This author used OC when describing the degree to which training is transferred, when the employee returns to work, and relates it to the behavior of the leader.

This early psychological lens is quite important and is preserved today, as the climate is considered to reside within the perceptions of individuals.

Likert establishes three types of variables that define the characteristics of an organization and that influence the individual perception of OC, in this sense the three variables are:

1. Causal Variables: Defined as independent variables, which are oriented to indicate the sense in which an organization evolves and obtains results. Among these variables are the organizational and administrative structure, decisions, competencies, and attitudes.

2. Intermediate Variables: They are oriented to measure the internal state of the organization, reflected in aspects such as motivation, performance, communication, and decision making.

3. Final Variables: They arise as a result of the effect of causal and intermediate variables, they are oriented to establish results obtained by the organization such as productivity, profit, and loss.

They explain important aspects of the behavior of individuals working in an organization, using concepts such as motivation and climate. They describe the situational and environmental determinants that most influence the behavior and perception of the individual. They postulate the existence of nine dimensions that would explain the OC existing in each company. Each of these dimensions relates to certain properties of the organization, such as Structure; Responsibility; Reward; Risk; Heat; Support; Performance standards; Conflict, and Identity.

They developed an OC measuring instrument,

level of analysis, "organizational climate". The distinction was important because it gave the researchers a shared terminology to clarify at what level of analysis a specific study was conducted. These authors from the beginning emphasized the idea that OC is a perception that resides within an individual, and only when perceptions are shared can there be an elevation of the level of construct analysis.

He proposed that OC studies should focus on specific issues such as service climate analysis or safety climate analysis. In essence, he argued that the OC, measures were too unfocused to generate convincing results, adopting this approach improved the research of the concept. 


\section{Continued}
Pritchard y Karasick
1973
These authors proposed to measure the organizational climate through eleven dimensions considered independent, descriptive, and related to the perceptual theory of the organizational
climate, which were: autonomy, conflict and cooperation, social relations, structure, remuneration, performance, motivation, status, flexibility, and innovation and, finally, centralization of decision making.

Continued

Third period (1986-1999): focus on the differences between culture and organizational climate.

Kozlowski y Doherty 1989

Schneider, White y Paul 1998

Denison

Schneider

Ashkanasy, Wilderom and Peterson.

Ashkanasy and Jackson.

Fourth period (2000-present): multilevel research and culture-climate integration

Kozlowski y Klein $\quad 2000$

They developed a greater emphasis on context analysis, to understand and explain employee behavior at work.

They conducted climate-focused studies, in which they addressed the most relevant components of the organizational environment to achieve a specific result. Such climates include climates that

Ehrhart, Schneider y Macey

They proposed that leadership is an antecedent of the OC, this principle oriented the research of scholars in that sense.

They oriented the research on the results, from here emerged very interesting research on the service climate and customer satisfaction.

This author considers that both concepts represent distinguishable perspectives. Thus, while culture refers to deeply rooted and assumed values and assumptions, climate refers to environmental factors consciously perceived and subject to organizational control, which translate into behavioral patterns. Even so, this same author considers that the climate can be linked to the construct of Culture.

Although they recognize differences between culture and climate, they emphasize that both concepts overlap and are complementary. the organization. The study of focused climates is currently the most common approach to studying climate among organizational researchers and has expanded to a wide variety of topics.

Lindell y Brandt

Schneider, Salvaggio and Subirats

Ostroff, Kinicki \& Muhammad

Zohar \& Hofmann, Schein

Source: Own elaboration based on Schneider et al., 2017; Ehrhart \& Schneider, 2016; Rodríguez, 2016; Acosta \& Venegas, 2010; Minchan Portal, 2020; Jaime Santana \& Araujo Cabrera, 2007; Ehrhart et al., 2013.

The study variables were: biographical characteristics and organizational climate. Table 2 describes the biographical characteristics used in the present investigation.

As can be seen in Table 2, biographical characteristics are factors that are easily defined and readily available; to a greater extent, they are simply those obtained from the information available in an employee's profile (Robbins et al., 2013). 
Table 2. Biographical characteristics of workers in small companies in the service sector of the city of Chihuahua.

\begin{tabular}{ccc}
\hline Variable & & Indicator \\
\hline & 1 & Age \\
Biographical characteristics & 2 & Sex \\
& 4 & Marital status \\
& 5 & Department \\
& 6 & Seniority \\
& 7 & School grade \\
\hline
\end{tabular}

Source: Own elaboration.

In the case of OC, the macro variable was described, through 12 factors, which were measured with an instrument based on the one proposed by (Chiang Vega et al., 2007), which is supported by the Likert Theory, and adapted to this research work. Table 3 describes the OC measurement factors.

As can be seen in Table 3, the instrument contains a total of 76 questions, which revolve around the values of the organization, beliefs, customs, physical environment, and business practices (García Solarte, 2009).

For data collection, the questionnaire technique was used as a method. The questionnaire was integrated into two sections: In the first section it contains the variable of biographical characteristics and in the second section the variable of OC was operationalized. The response options used were five and each of them was identified with the respective code: totally agree (5); agree (4), neither agree/ nor disagree (3); disagree (2) and strongly disagree (1). The measurement instrument was delivered personally to the employees of the companies evaluated with the help of the Human Resources department, 270 surveys were delivered, and responses were only obtained from 47 of them.

The data was managed through SPSS. This allowed organizing and integrating the data, to achieve the research objectives, the following were performed: Cronbach's Alpha reliability analysis, bivariate correlation analysis, mean $\mathrm{K}$ analysis, and chi-square analysis.

\section{Results}

The results were organized according to the logical sequence of the research and the proposed objectives, they are described below:

Validity and reliability tests were developed for the instrument used, which showed an index of 0.929 .

To meet the objective of describing the biographical characteristics, a descriptive analysis was carried out, which is shown in Table 4.

As can be seen in Table 4, the number of men and women is very balanced, $62 \%$ of the employees are married, more than half (53\%) have a university edu- 
cation, 53\% are between 25 and 36 years, which brings a good youth bonus to the workforce, which is related to the seniority indicator, where $66 \%$ are under nine years of age.

Within the sociodemographic indicators, Age and Seniority were evaluated as quantitative variables. The other indicators were measured as qualitative variables. Table 5 shows their analysis.

Table 3. OC measurement factors of small companies in the service sector of the city of Chihuahua.

\begin{tabular}{llcc}
\hline Variable & & Factor & Ítems \\
\hline & 1 & Internal Communication & 14 \\
& 3 & Recognition & 10 \\
& 4 & Interpersonal Relationships at Work & 8 \\
& 5 & Quality at work & 8 \\
Organizational & 6 & Decision making & 6 \\
Climate & 7 & Physical environment & 6 \\
& 8 & Objectives of the institution & 3 \\
& 9 & Commitment & 4 \\
& 10 & Delegation of activities and functions & 5 \\
& 11 & External coordination & 5 \\
& 12 & Productivity efficiency & 3 \\
\hline
\end{tabular}

Source: Own elaboration.

Table 4. Descriptive analysis of the biographical characteristics of the employees of small companies in the service sector of the city of Chihuahua.

\begin{tabular}{cccccc}
\hline Sex & \multicolumn{2}{c}{ Men 51\% } & \multicolumn{3}{c}{ Women 49\% } \\
\hline Marital status & Married 62\% & Single 32\% & \multicolumn{3}{c}{ Other 6\% } \\
\hline $\begin{array}{c}\text { Department of } \\
\text { Work }\end{array}$ & Administrative & Units 15\% & Workshop & Spare parts & Other \\
& $26 \%$ & & $17 \%$ & $9 \% 9 \%$ & $25 \%$ \\
School grade & University & high school & Junior high No response & Other \\
& $53 \%$ & $11 \%$ & school 13\% & $19 \%$ & $4 \%$ \\
Type of & Administrative & Operational & & No response5\% & \\
personnel & $53 \%$ & $32 \%$ & & & \\
& $31-36$ & $25-30$ & $37-42$ & $43-48$ & Remainder \\
Age (years)) & $32 \%$ & $21 \%$ & $19 \%$ & $13 \%$ & $15 \%$ \\
& $0-4$ & $5-9$ & $10-14$ & $15-19$ & Remainder \\
Seniority (years) & $38 \%$ & $28 \%$ & $9 \%$ & $17 \%$ & $8 \%$ \\
\hline
\end{tabular}

Source: Own elaboration. 
Table 5. Measures of Central Tendency (MD) and Measures of Dispersion (MD) of the biographical characteristics, Age, and Seniority of the employees of small companies in the service sector of the city of Chihuahua.

\begin{tabular}{cccccc}
\hline Characteristic & Mean & Median & Mode & Standard deviation & Coefficient of Variation \\
\hline \multicolumn{7}{c}{} \\
Age & 33 & 35 & 27 & 13 & 0.39 \\
Seniority & 7 & 5 & 0 & 7 & 1.01 \\
\hline
\end{tabular}

Source: Own elaboration.

In Table 5, it can be observed that the measures of central tendency (MTC) (mean, median, and mode) for the variable Age are similar; However, the measures of dispersion (MD) as the standard deviation, registered 13 years and the coefficient of variation is relatively high and is located almost at $40 \%$. Regarding the Age variable, the MTCs do not represent a trend or behavior towards the center of the data. The MDs show a large dispersion expressed with the coefficient of variation, with a value above $100 \%$.

To meet the objective of making a diagnosis of OC, in the small companies of the service sector of the city of Chihuahua, a descriptive analysis of the organizational climate was carried out, which is shown in Table 6.

It can be observed in Table 6 , that $71 \%$ of the employees perceive the organizational climate adequately, through the 12 dimensions evaluated; However, it can be observed that $20 \%$ of those surveyed indifferently perceive the organizational climate, neither agree nor disagree with what they perceive and the remaining 9\% manifest having an inadequate perception of the evaluated dimensions of Climate Organizational.

Bivariate correlations were also made between the OC factors evaluated, which are presented in Table 7.

As can be seen, only three interesting relationships were detected that are located above 0.750 , and one of them stands out for presenting a correlation of $100 \%$, which was presented between the factors Interpersonal relationships at work, with the Recognition factor.

To identify the relationship between biographical characteristics and OC, an analysis of $\mathrm{k}$ means and a Chi-square analysis was carried out. Which are shown below.

Table 8 shows the grouping or conglomerates of the responses considering the biographical characteristics of age and the factors of the organizational climate.

In Table 8, it can be seen that the clusters by Age show two notable results represented by three groups. The first of these is that individuals who are between 37 and 42 years of age, who, in their perception, agree or are indifferent to the situation of the organizational climate in a proportion of 7 and 5 dimensions respectively (Group 1). On the other hand, the personnel representing the age between 31 and 36 years show two antagonistic positions (Groups 2 and 3). 
Some of them, in general terms, perceive the 12 factors evaluated as adequate, that is, they feel satisfied; However, others of the same age group perceive the OC factors evaluated as inadequate. The reason for this unfavorable perception of the climate can be attributed to various factors that have to do with the management of human capital in companies.

Table 6. Summary of results of the perception of the organizational climate of employees of small companies in the service sector of the city of Chihuahua.

\begin{tabular}{|c|c|c|c|c|}
\hline & Respon & option & & \\
\hline \multirow{3}{*}{ Factor } & $\begin{array}{l}\text { Fully } \\
\text { Agree }\end{array}$ & I agree & $\begin{array}{l}\text { Neither agree/ } \\
\text { Nor disagree }\end{array}$ & Disagreeing $\begin{array}{l}\text { Strongly } \\
\text { disagree }\end{array}$ \\
\hline & \multicolumn{4}{|l|}{$(\%)$} \\
\hline & 1 & & 2 & 3 \\
\hline 1. Internal communication & 73 & & 19 & 8 \\
\hline 2. Recognition & 53 & & 29 & 18 \\
\hline $\begin{array}{l}\text { 3. Interpersonal relationships } \\
\text { at work }\end{array}$ & 71 & & 22 & 7 \\
\hline 4. Quality at work & 77 & & 18 & 5 \\
\hline 5. Decision making & 61 & & 25 & 14 \\
\hline 6. Physical environment & 59 & & 19 & 22 \\
\hline $\begin{array}{l}\text { 7. Objectives of the } \\
\text { institution }\end{array}$ & 89 & & 8 & 3 \\
\hline 8. Commitment & 88 & & 9 & 3 \\
\hline 9. Adapting to change & 80 & & 14 & 6 \\
\hline $\begin{array}{l}\text { Delegation of activities } \\
\text { and functions }\end{array}$ & 54 & & 38 & 8 \\
\hline 11. External coordination & 77 & & 18 & 5 \\
\hline 12. Productivity efficiency & 70 & & 18 & 12 \\
\hline AVERAGE & 71 & & 20 & 9 \\
\hline
\end{tabular}

Source: Own elaboration.

Table 7. Bivariate correlations of the factors of the organizational climate of small companies in the service sector of the city of Chihuahua.

\begin{tabular}{|c|c|c|c|c|c|}
\hline Organizational Climat & te Factors & Recognition & Commitment & $\begin{array}{c}\text { External } \\
\text { Coordination }\end{array}$ & $\begin{array}{c}\text { Level of } \\
\text { significance }\end{array}$ \\
\hline $\begin{array}{c}\text { Internal } \\
\text { Communication }\end{array}$ & Pearson & & & 0.776 & 0.05 \\
\hline $\begin{array}{c}\text { Interpersonal } \\
\text { Relationships at } \\
\text { Work }\end{array}$ & Pearson & 1.000 & & & 0.05 \\
\hline $\begin{array}{l}\text { Objectives in the } \\
\text { Institution }\end{array}$ & Pearson & & 0.809 & & 0.05 \\
\hline
\end{tabular}

Source: Own elaboration. 
Table 8. Analysis of K Means (Clusters) for the biographical characteristic of Age Vs. Organizational Climate factors in small companies in the service sector of the city of Chihuahua.

\begin{tabular}{cccc}
\hline & \multicolumn{3}{c}{ Conglomerate } \\
\cline { 2 - 4 } Age (years) & 1 & 2 & 3 \\
\hline Internal communication & $37-42$ & $31-36$ & $31-36$ \\
Recognition & 2 & 3 & 5 \\
Interpersonal relationships at work & 3 & 2 & 5 \\
Quality at work & 3 & 2 & 5 \\
Decision making & 2 & 2 & 5 \\
Physical environment & 3 & 2 & 5 \\
Objectives of the institution & 3 & 2 & 5 \\
Commitment & 2 & 2 & 5 \\
Adapting to change & 2 & 1 & 5 \\
Delegation of activities and functions & 2 & 2 & 4 \\
External coordination & 3 & 2 & 3 \\
Productivity efficiency & 2 & 2 & 3 \\
Average & 2 & 2 & 4 \\
SD & 2.42 & 2.00 & 4.50 \\
\hline
\end{tabular}

Measurement scale: Strongly agree $=1$; Agree $=2$; Neither agree nor disagree $=3$; Disagree $=4$ and Strongly disagree $=5$. Source: Own elaboration.

Table 9 shows the grouping or conglomerates of the responses considering the biographical characteristics of the marital status and the factors of the organizational climate.

Regarding marital status, married people represented $62 \%$ of those surveyed and single people $32 \%$. In this evaluation, three well-defined groups were detected in terms of their position related to the organizational climate. People who are married show two perceptions (Groups 1 and 2). A group of married couples perceives the evaluated OC factors as inadequate, with which they completely disagree, but another group of married couples perceives the factors adequately. The third group is represented by singles, and almost all of them perceive the $\mathrm{OC}$ factors evaluated as adequate.

Table 10 shows the grouping or conglomerates of the responses considering the biographical characteristic of sex and the factors of the organizational climate.

As shown in Table 10, the perception of the genders, concerning the OC factors evaluated, is well defined. Male subjects perceive the evaluated factors as inadequate and some are indifferent to them. The female sex perceives differently, they adequately evaluate the OC factors. This is significant for the company since the perception of women could suggest human capital management with a gender equity perspective, which is very positive in modern organizations. 
Table 9. Analysis of K Means (Clusters) for the biographical characteristic of Marital Status vs. Organizational Climate factors in small companies in the service sector of the city of Chihuahua.

\begin{tabular}{cccc}
\hline & \multicolumn{3}{c}{ Conglomerate } \\
\cline { 2 - 4 } & 1 & 2 & 3 \\
\hline Marital status & Married & Married & Single \\
\hline Internal communication & 5 & 2 & 2 \\
Recognition & 5 & 2 & 3 \\
Interpersonal relationships at work & 5 & 2 & 3 \\
Quality at work & 5 & 2 & 2 \\
Decision making & 5 & 2 & 2 \\
Physical environment & 5 & 2 & 2 \\
Objectives of the institution & 5 & 2 & 2 \\
Commitment & 5 & 2 & 2 \\
Adapting to change & 4 & 2 & 2 \\
Delegation of activities and functions & 3 & 2 & 2 \\
External coordination & 4 & 2 & 2 \\
Productivity efficiency & 4 & 2 & 2 \\
Average & 4.58 & 2.00 & 2.17 \\
SD & 0.64 & 0.00 & 0.37 \\
\hline
\end{tabular}

Measurement scale: Strongly agree $=1$; Agree $=2$; Neither agree nor disagree $=3$; Disagree $=4$ and Strongly disagree $=5$. Source: Own elaboration.

Table 10. Analysis of K Means (Clusters) for the biographical characteristic of Sex vs. Organizational Climate factors in small companies in the service sector of the city of Chihuahua.

\begin{tabular}{ccc}
\hline & \multicolumn{2}{c}{ Conglomerate } \\
\cline { 2 - 3 } Sex & 1 & 2 \\
\hline Internal communication & Male & Female \\
Recognition & 4 & 2 \\
Interpersonal relationships at work & 4 & 2 \\
Quality at work & 4 & 2 \\
Decision making & 4 & 2 \\
Physical environment & 4 & 2 \\
Objectives of the institution & 4 & 2 \\
Commitment & 3 & 2 \\
Adapting to change & 3 & 2 \\
Delegation of activities and functions & 3 & 2 \\
External coordination & 3 & 2 \\
Productivity efficiency & 4 & 2 \\
Average & 4 & 2 \\
DE & 3.67 & 2.00 \\
\hline
\end{tabular}

Measurement scale: Strongly agree $=1$; Agree $=2$; Neither agree nor disagree $=3$; Disagree $=4$ and Strongly disagree $=5$. Source: Own elaboration. 
Table 11 shows the grouping or conglomerates of the responses considering the biographical characteristic Department and the factors of the organizational climate.

It is interesting to note that the Spare Parts, Units, and Workshop departments bring together $9 \%, 15 \%$, and $17 \%$ of the employees, that is, they do not represent more than $50 \%$ of the company's personnel; However, as shown in Table 11, the position of this personnel, depending on the department in which they work, is forceful and shows different perceptions concerning the organizational climate. In this sense, the personnel working in the Parts department show an indifferent perception or agree with the OC detected in the company. The workers in the Units department perceive an adequate OC and agree with what is happening in the company. But the people who work in the Workshop, perceive the OC as inappropriate and are in disagreement or annoyance, these results may suggest that the inadequate physical environment leads to this negative perception of the rest of the factors evaluated.

Table 12 shows the grouping or conglomerates of the responses considering the biographical characteristic Seniority and the factors of the organizational climate.

Table 11. Analysis of K Means (Clusters) for the biographical characteristic of Department vs. Organizational Climate factors in small companies in the service sector of the city of Chihuahua.

\begin{tabular}{cccc}
\hline & \multicolumn{3}{c}{ Conglomerate } \\
\cline { 2 - 4 } & 1 & 2 & 3 \\
\hline Department & Spare Parts & Workshop & units \\
\hline Internal communication & 2 & 2 & 5 \\
Recognition & 3 & 2 & 5 \\
Interpersonal relationships at work & 3 & 2 & 5 \\
Quality at work & 2 & 2 & 5 \\
Decision making & 3 & 2 & 5 \\
Physical environment & 3 & 2 & 5 \\
Objectives of the institution & 2 & 1 & 5 \\
Commitment & 2 & 2 & 4 \\
Adapting to change & 2 & 2 & 3 \\
Delegation of activities and functions & 3 & 2 & 4 \\
External coordination & 2 & 2 & 4 \\
Productivity efficiency & 2 & 1.92 & 4.58 \\
Average & 2.42 & 0.29 & 0.67 \\
SD & 0.51 & 29 & 5 \\
\hline
\end{tabular}

Measurement scale: Strongly agree $=1$; Agree $=2$; Neither agree nor disagree $=3$; Disagree $=4$ and Strongly disagree $=5$. Source: Own elaboration. 
Table 12. Analysis of K Means (Clusters) for the biographical characteristic of Seniority vs. The factors of Organizational Climate in small companies in the service sector of the city of Chihuahua.

\begin{tabular}{cccc}
\hline & \multicolumn{3}{c}{ Conglomerate } \\
\cline { 2 - 4 } Seniority (years) & 1 & 2 & 3 \\
\hline Internal communication & $10-14$ & $5-9$ & $0-4$ \\
Recognition & 2 & 2 & 5 \\
Interpersonal relationships at work & 2 & 3 & 5 \\
Quality at work & 2 & 3 & 5 \\
Decision making & 1 & 2 & 5 \\
Physical environment & 2 & 3 & 5 \\
Objectives of the institution & 2 & 3 & 5 \\
Commitment & 1 & 2 & 5 \\
Adapting to change & 1 & 2 & 5 \\
Con & 2 & 2 & 4 \\
External coordination & 2 & 2 & 3 \\
Productivity efficiency & 1 & 2 & 4 \\
Average & 2 & 2 & 4 \\
SD & 1.67 & 2.33 & 4.58 \\
\hline
\end{tabular}

Measurement scale: Strongly agree $=1$; Agree $=2$; Neither agree nor disagree $=3$; Disagree $=4$ and Strongly disagree $=5$. Source: Own elaboration.

In Table 12, you can see the impact of Seniority, it seems that the more years of permanence, the better perception of OC is had, this could be an interesting result, there is some evidence that shows that Seniority positively influences the adequate perception of the organization by employees (Robbins et al., 2013). Table 12 shows well-defined positions; People with the longest Seniority (10 to 14 years of work) state that they agree on all the OC factors evaluated. The group that is between 5 to 9 years, show a certain indifference or partially agree on this evaluation. But people who are 0 to 4 years, do not think the same as the two previous groups and express a total disagreement with what is lived in the corporation. This could be explained by the fact that, in human capital management policies, it is common for benefits, permits, promotions, and rewards to be assigned based on seniority within the organization.

Table 13 shows the grouping or conglomerates of the responses considering the biographical characteristic of School grade and the factors of the organizational climate.

Education grade represents an important factor in any organization. In the present research, $53 \%$ of the participants have a University education, and high school level is present in $11 \%$ of those evaluated. As can be seen in Table 13, there are two groups of university workers who have opposite perceptions of the 
organizational climate (Group 1 and 3). Group 1 perceives the OC as inappropriate and disagrees with the evaluated factors, while other university students (Group 3) are indifferent to the work context. This could be attributed to the fact that in Mexico around $45 \%$ of university students are underemployed (Alfaro Ponce et al., 2013), this implies an interesting challenge for companies in terms of human resource management. Concerning Group 2, workers with a high school degree, their perception is good for the dimensions of the organizational climate, that is, it can be assumed that academic training is coinciding with what these people do and receive within the organization.

Table 14 shows the grouping or conglomerates of the responses considering the biographical characteristic Type of personnel and the factors of the organizational climate.

The type of personnel is defined according to the work area. In this case, the administrative staff represents $26 \%$ of the total workers (Group 1), while the operational staff (Group 2) comprises the employees who are located in the Workshop, Units, and Spare Parts departments and represent 32\%. As can be seen in Table 14, these two groups differ in their perception of the OC factors evaluated. The Administrative Group perceives the climate with disagreement and some indifference, while the Operating Group perceives the OC adequately and agrees with what is happening in their work environment.

Table 13. Analysis of K Means (Clusters) for the biographical characteristic of School grade vs. Organizational Climate factors in small companies in the service sector of the city of Chihuahua.

\begin{tabular}{cccc}
\hline & \multicolumn{3}{c}{ Conglomerate } \\
\cline { 2 - 4 } & 1 & 2 & 3 \\
\hline School Grade & University & High School & University \\
\hline Internal communication & 5 & 2 & 2 \\
Recognition & 5 & 2 & 3 \\
Interpersonal relationships at work & 5 & 2 & 3 \\
Quality at work & 5 & 2 & 2 \\
Decision making & 5 & 2 & 3 \\
Physical environment & 5 & 2 & 3 \\
Objectives of the institution & 5 & 2 & 2 \\
Commitment & 5 & 1 & 2 \\
Adapting to change & 4 & 2 & 2 \\
Delegation of activities and functions & 3 & 2 & 3 \\
External coordination & 4 & 2 & 3 \\
Productivity efficiency & 4 & 2 & 3 \\
Average & 4.58 & 1.92 & 2.58 \\
SD & 0.67 & 0.29 & 0.51 \\
\hline
\end{tabular}

Measurement scale: Strongly agree $=1$; Agree $=2$; Neither agree nor disagree $=3$; Disagree $=4$ and Strongly disagree $=5$. Source: Own elaboration. 
Table 14. Analysis of K Means (Clusters) for the biographical characteristic of Type of personnel vs. Organizational Climate factors in small companies in the service sector of the city of Chihuahua.

\begin{tabular}{ccc}
\hline & \multicolumn{2}{c}{ Conglomerate } \\
\cline { 2 - 3 } Type of personnel & 1 & 2 \\
\hline Internal communication & Administrative & Operational \\
Recognition & 4 & 2 \\
Interpersonal relationships at work & 4 & 2 \\
Quality at work & 4 & 2 \\
Decision making & 4 & 2 \\
Agree on Physical Environment & 4 & 2 \\
Objectives of the institution & 4 & 2 \\
Commitment & 3 & 2 \\
Adapting to change & 3 & 2 \\
Delegation of activities and functions & 3 & 2 \\
External coordination & 3 & 2 \\
Productivity efficiency & 4 & 2 \\
Average & 4 & 2 \\
SD & 3.67 & 2.00 \\
\hline
\end{tabular}

Measurement scale: Strongly agree $=1 ;$ Agree $=2$; Neither agree nor disagree $=3$; Disagree $=4$ and Strongly disagree $=5$. Source: Own elaboration.

In addition, the chi-square statistical test was carried out to identify if biographical characteristics, as an independent variable, and the Organizational Climate factors, as a dependent variable, have any relationship.

The hypothesis for the chi-square test was defined as follows:

H0: Biographical characteristics and organizational climate factors are independent; that is, there is no relationship between them.

H1: Biographical characteristics and organizational climate factors are dependent; that is, there is a relationship between them.

The decision rule is: $\mathrm{H} 0$ is rejected: if $\mathrm{x} 2>\mathrm{x} 2 \mathrm{u}$

532 evaluations or crossovers were carried out (7 biographical characteristics vs 76 questions of the OC factors) and 42 relationships were identified between these indicators, which represented $7.9 \%$ of the possible interactions between these variables.

Table 15 shows the Chi-Square test between the biographical characteristics of age and sex Vs. the OC factors.

As can be seen in Table 15, concerning age, the Chi-Square shows that there are three factors of the organizational climate: Recognition; Quality at work, and Physical environment, which are impacting this perception. This indicates that the age of the employees is a factor that affects the differentiated perception of OC in the company. 
Table 15. Chi-square test between the biographical characteristics of Age and Sex and the factors of the organizational climate in small companies in the service sector of the city of Chihuahua.

\begin{tabular}{|c|c|c|c|c|c|c|}
\hline \multicolumn{7}{|c|}{ CHI-SQUARE OF PEARSON } \\
\hline $\begin{array}{l}\text { Biographical } \\
\text { Characteristic }\end{array}$ & OC Factors & Questions & Value $\mathrm{x} 2$ & $\mathrm{gl}$ & Value $\mathrm{x} 2 \mathrm{u}$ & $\begin{array}{l}\text { Ns } \\
\mathrm{P}(<0.05)\end{array}$ \\
\hline \multirow[b]{3}{*}{ Age } & Recognition & 7. Quality performance at a reward? & 125.207 & 100 & 124.3421 & .05 \\
\hline & Quality at work & 1. Do we take quality really? & 125.725 & 100 & 124.3421 & .05 \\
\hline & $\begin{array}{l}\text { Physical } \\
\text { environment }\end{array}$ & $\begin{array}{l}\text { 1. Does the physical environment improve the } \\
\text { well-being and efficiency of your } \\
\text { Department/Service/Unit? }\end{array}$ & 124.902 & 100 & 124.3421 & .05 \\
\hline $\begin{array}{l}\text { Biographical } \\
\text { Characteristic }\end{array}$ & OC Factors & Questions & Value $\mathrm{x} 2$ & gl & Value $x 2 \mathrm{u}$ & $\begin{array}{l}\text { Ns } \\
\mathrm{P}(<0.05)\end{array}$ \\
\hline \multirow{4}{*}{ Sex } & \multirow{2}{*}{$\begin{array}{l}\text { Internal } \\
\text { communication }\end{array}$} & $\begin{array}{l}\text { 1. Do you feel free to talk to your superior about } \\
\text { subjects related to your work? }\end{array}$ & 24.133 & 2 & 5.9915 & .05 \\
\hline & & $\begin{array}{l}\text { 2. Is the relationship with your co-workers } \\
\text { appropriate? }\end{array}$ & 8.083 & 3 & 7.8147 & .05 \\
\hline & \multirow{2}{*}{ Delegation } & 1. Is there enough delegation? & 10.567 & 3 & 7.8147 & .05 \\
\hline & & 2. Are the skills of officials used most advantageously? & 8.421 & 3 & 7.8147 & .05 \\
\hline
\end{tabular}

Source: Own elaboration. 
Table 16. Chi-square test between the biographical characteristics of Marital Status, Department and Seniority and the factors of the organizational climate in small companies in the service sector of the city of Chihuahua.

\begin{tabular}{|c|c|c|c|c|c|c|}
\hline \multicolumn{7}{|c|}{ CHI-SQUARE OF PEARSON } \\
\hline $\begin{array}{l}\text { Biographical } \\
\text { Characteristic }\end{array}$ & OC Factors & Questions & Value $\mathrm{x} 2$ & $\mathrm{gl}$ & Value $\mathrm{x} 2 \mathrm{u}$ & $\begin{array}{l}\text { Ns } \\
\mathrm{P}(<0.05)\end{array}$ \\
\hline \multirow[b]{2}{*}{ Marital status } & Recognition & 7. Is quality performance rewarded? & 29.170 & 16 & 26.2962 & .05 \\
\hline & $\begin{array}{l}\text { Adapting to } \\
\text { change }\end{array}$ & $\begin{array}{l}\text { 1. Do we know what the progress of our } \\
\text { Department/Service/Unit is? }\end{array}$ & 27.096 & 12 & 21.0261 & .05 \\
\hline $\begin{array}{l}\text { Biographical } \\
\text { Characteristic }\end{array}$ & OC Factors & Questions & Value $\mathrm{x} 2$ & $\mathrm{gl}$ & Value $\mathrm{x} 2 \mathrm{u}$ & $\begin{array}{l}\text { Ns } \\
\mathrm{P}(<0.05)\end{array}$ \\
\hline \multirow{6}{*}{ Department } & \multirow{2}{*}{$\begin{array}{l}\text { Internal } \\
\text { communication }\end{array}$} & $\begin{array}{l}\text { 1. Do you feel free to talk to your superior about } \\
\text { subjects related to your work? }\end{array}$ & 41.443 & 12 & 21.0261 & .05 \\
\hline & & $\begin{array}{l}\text { 10. Is our information shared with the rest of the } \\
\text { team? }\end{array}$ & 31.605 & 18 & 28.8693 & .05 \\
\hline & $\begin{array}{l}\text { Interpersonal } \\
\text { Relationships at Work }\end{array}$ & 6. Do we trust each other? & 41.949 & 24 & 36.4150 & .05 \\
\hline & $\begin{array}{l}\text { Objectives of the } \\
\text { institution }\end{array}$ & 2. Do you know them? & 34.627 & 18 & 28.8693 & .05 \\
\hline & External coordination & $\begin{array}{l}\text { 1. Do we work well with the rest of the } \\
\text { Departments/Services/Units? }\end{array}$ & 29.534 & 18 & 28.8693 & .05 \\
\hline & Productivity efficiency & $\begin{array}{l}\text { 1. Does your Department/Service/Unit respond } \\
\text { to the organization's expectations regarding its } \\
\text { efficiency and productivity? }\end{array}$ & 29.533 & 18 & 28.8693 & .05 \\
\hline $\begin{array}{l}\text { Biographical } \\
\text { Characteristic }\end{array}$ & OC Factors & Questions & Value $\mathrm{x} 2$ & $\mathrm{gl}$ & Value $\mathrm{x} 2 \mathrm{u}$ & $\begin{array}{l}\text { Ns } \\
\mathrm{P}(<0.05)\end{array}$ \\
\hline Seniority & Recognition & 6. Have we been part of the good results? & 124.274 & 96 & 113.1452 & .05 \\
\hline
\end{tabular}

Source: Own elaboration.

Table 17 shows the Chi-Squared test between the biographical characteristics of School grade and Type of personnel Vs. OC factors.

Table 17 shows the chi-square results for the biographical characteristic of School grade, in which the factors of the work environment that are related to the university personnel who perceive the $\mathrm{OC}$ as inappropriate are observed, they are not following the Internal Communication and Recognition, highlighting freedom of expression with aspects related to work and, on the other hand, the fact of receiving criticism or calls for attention instead of receiving praise. Regarding the biographical characteristics of Type of personnel, which was classified as Administrative (53\%) and Operational (32\%). The mean $\mathrm{K}$ analysis shows these two groups with antagonistic perceptions. The administrative staff shows disagreement or indifference towards the OC factors, while the operational employees perceive the $\mathrm{OC}$ factors that were evaluated as adequate. In this case, the chi-square analysis indicates which are the OC indicators that are influencing these differences in perception. This result should be specified since the differences in perception are presented in 10 of the 12 dimensions evaluated. This means that company policies, treatment, and labor relations among others, are not perceived similarly by company employees. 
Table 17. Chi-square test between the biographical characteristics of School grade and Type of personnel and the factors of the organizational climate in small companies in the service sector of the city of Chihuahua.

\begin{tabular}{|c|c|c|c|c|c|c|}
\hline \multicolumn{7}{|c|}{ CHI-SQUARE OF PEARSON } \\
\hline $\begin{array}{l}\text { Biographical } \\
\text { Characteristic }\end{array}$ & Factors del OC & Questions & Value $\mathrm{x}$ & & Value $\mathrm{x} 2 \mathrm{u}$ & \\
\hline \multirow{2}{*}{$\begin{array}{l}\text { Level of } \\
\text { schooling }\end{array}$} & $\begin{array}{l}\text { Internal } \\
\text { communication }\end{array}$ & $\begin{array}{l}\text { 1. Do you feel free to talk to your superior about subjects related to } \\
\text { your work? }\end{array}$ & 27.125 & 8 & 15.5073 & .05 \\
\hline & Recognition & $\begin{array}{l}10 . \text { Does the official who has been called by the boss expect praise } \\
\text { rather than criticism? }\end{array}$ & 29.591 & 16 & 26.2962 & .05 \\
\hline $\begin{array}{l}\text { Biographical } \\
\text { Characteristic }\end{array}$ & OC Factors & Questions & \multicolumn{2}{|c|}{ Value $\mathrm{x} 2 \mathrm{gl}$} & \multicolumn{2}{|l|}{ Value $\mathrm{x} 2 \mathrm{u}$} \\
\hline \multirow{24}{*}{$\begin{array}{l}\text { Type of } \\
\text { personnel }\end{array}$} & \multirow{7}{*}{ Communication } & $\begin{array}{l}\text { 1. Do you feel free to talk to your superior about subjects related to } \\
\text { your work? }\end{array}$ & 94.000 & 4 & 9.4877 & .05 \\
\hline & & 2. Is the relationship with your co-workers appropriate? & 13.405 & 6 & 12.5916 & .05 \\
\hline & & $\begin{array}{l}\text { 5. Does your boss care to explain everything very well so that there } \\
\text { is no confusion? }\end{array}$ & 19.508 & 8 & 15.5073 & .05 \\
\hline & & $\begin{array}{l}\text { 6. Do you consider that you are given enough information, for the } \\
\text { time being, to do your job well? }\end{array}$ & 21.877 & 8 & 15.5073 & .05 \\
\hline & & 11. Are our communication mechanisms adequate? & 17.259 & 8 & 15.5073 & .05 \\
\hline & & 14. Do we respect each other's time? & 19.619 & 18 & 15.5073 & .05 \\
\hline & & 1. Do we have a good time working together? & 22.05 & 6 & 12.5916 & .05 \\
\hline & \multirow{3}{*}{$\begin{array}{l}\text { Interpersonal } \\
\text { relationships } \\
\text { at work }\end{array}$} & 3. Do we feel safe in our work? & 21.664 & 8 & 15.5073 & .05 \\
\hline & & 6. Do we trust each other? & 20.721 & 8 & 15.5073 & .05 \\
\hline & & 7. Do we talk to each other, but not to each other? & 16.177 & 8 & 15.5073 & .05 \\
\hline & \multirow{2}{*}{ Quality } & 2. Do we know our strengths and weaknesses? & 15.976 & 8 & 15.5073 & .05 \\
\hline & & 3. Do we regularly evaluate the quality of our activities? & 15.238 & 6 & 12.5916 & .05 \\
\hline & Decision making & $\begin{array}{l}\text { 3. Do you think that decisions in your unit are made with workers } \\
\text { in mind? }\end{array}$ & 16.288 & 8 & 15.5073 & .05 \\
\hline & Environment & $\begin{array}{l}\text { 6. Does your Department/Service/Unit have the necessary } \\
\text { equipment and supplies for the development of its functions? }\end{array}$ & 15.799 & 8 & 15.5073 & .05 \\
\hline & \multirow{3}{*}{$\begin{array}{l}\text { Objectives of the } \\
\text { institution }\end{array}$} & 2. Do you know them? & 14.410 & 6 & 12.5916 & .05 \\
\hline & & 3. Do you agree with them? & 16.885 & 8 & 15.5073 & .05 \\
\hline & & 3. Do you feel on your shirt? & 14.787 & 6 & 12.5916 & .05 \\
\hline & Commitment & $\begin{array}{l}\text { Do we feel responsible for the successes and failures of our } \\
\text { Department/Service/Unit? }\end{array}$ & 12.717 & 6 & 12.5916 & .05 \\
\hline & \multirow{2}{*}{$\begin{array}{l}\text { Adapting to } \\
\text { change }\end{array}$} & $\begin{array}{l}\text { 1. Do we know what the progress of our Department/Service/Unit } \\
\text { is? }\end{array}$ & 23.274 & 6 & 12.5916 & .05 \\
\hline & & 4. Are we willing to adapt to change? & 17.592 & 8 & 15.5073 & .05 \\
\hline & \multirow{2}{*}{$\begin{array}{l}\text { External } \\
\text { coordination }\end{array}$} & $\begin{array}{l}\text { 3. Do you know what the users of your Department/Service/Unit } \\
\text { require? }\end{array}$ & 23.067 & 8 & 15.5073 & .05 \\
\hline & & 4. How do you evaluate management communication? & 13.789 & 6 & 12.5916 & .05 \\
\hline & \multirow{2}{*}{$\begin{array}{l}\text { Productivity } \\
\text { efficiency }\end{array}$} & $\begin{array}{l}\text { 1. Does your Department/Service/Unit respond to the } \\
\text { organization's expectations regarding its efficiency and } \\
\text { productivity? }\end{array}$ & 13.261 & 6 & 12.5916 & .05 \\
\hline & & $\begin{array}{l}\text { 2. Are the tasks always carried out on time, according to } \\
\text { established rules, and making the best use of resources? }\end{array}$ & 18.187 & 8 & 15.5073 & .05 \\
\hline
\end{tabular}

Source: Own elaboration. 
According to the results presented, it is possible to point out that no elements were found to reject the research hypothesis, which stated that there is a relationship between biographical characteristics and organizational climate factors. According to the results obtained in the correlation analysis, the OC factors that showed a greater relationship with the biographical characteristics are recognition, interpersonal relationships at work, and internal communication.

\section{Discussion or Conclusion}

Based on the study objectives, hypotheses results obtained, and the context on which this research was carried out, the following is concluded:

The information of the biographical characteristics is difficult to obtain since the employees refuse to answer the research instruments, the argument that they generally raise is that said information is personal and sensitive, that, when mentioning, for example, the state Civil and educational level, just to mention a few, colleagues label and discriminate against them, causing difficulties and problems in the work environment.

An important limitation is that in work environments there is little support for research, the data collection process is difficult and in the case of questionnaires, employees do not want to invest time to answer it.

The diagnosis of OC and the biographical characteristics are very valuable tools since they provide information about the variables and processes that impact the organizational behavior system, this undoubtedly gives a guide to the development of plans and programs, which can be implemented through the human capital management area, to improve behaviors and attitudes and with this, help improve the overall performance of organizations.

For organizations to have an adequate $\mathrm{CO}$, they must focus on responsible human capital management and have leadership that considers the importance of workers, who are aware that the human factor is the most important asset, considering factors such as communication, recognition, commitment, and interpersonal relationships among others; For people to improve their perception of the organization for which they work, which will impact their work behavior.

Finally, it is important to note that a challenge that can be addressed in future research, is to delve into the impact that OC factors have on the performance of the organization.

\section{Conflicts of Interest}

The authors declare no conflicts of interest regarding the publication of this paper.

\section{References}

Acosta, B., \& Venegas, C. (2010). Clima organizacional en una empresa cervecera: Un estudio exploratorio. Revista de Investigación en Psicología, 13, 163-172.

Alfaro Ponce, B., Padilla Mendoza, E., \& Rodríguez Solera, C. (2013). Panorama de la In- 
serción Laboral de los Universitarios en México. In Universidad de Guanajuato (Ed.), XII Congreso Nacional De Investigación Educativa (pp. 1-11). Consejo Mexicano de Investigación Educativa.

http://www.comie.org.mx/congreso/memoriaelectronica/v12/doc/1014.pdf

Arano, R., Escudedo, J., \& Delfín, L. (2016). El Origen del Clima Organizacional, desde una Perspectiva de las Escuelas de la Administración: Una Aproximación. Ciencia Administrativa, No. 1, 9-14.

Araque, Y. del V. C., Córdoba, V. H. M., \& Meriño, C. M. de. (2018). El clima organizacional en el emprendimiento sostenible. Revista Escuela de Administración de Negocios, 84 , Article No. 84.

Balla Carchi, S. M., \& Vera sánchez, S. D. J. (2018). Análisis de una Auditoría Socioloaboral y su Incidencia en el Clima Organizacional «Caso UNEMI-FACAC». Repositorio de la Universidad Estatal de Milagro.

http://repositorio.unemi.edu.ec//handle/123456789/4041

http://repositorio.unemi.edu.ec/bitstream/123456789/4041/1/AN\%c3\%81LISIS\%20DE \%20UNA\%20AUDITOR\%c3\%8dA\%20SOCIOLABORAL\%20\%20Y\%20SU\%20INCID ENCIA\%20EN\%20EL\%20CLIMA\%20ORGANIZACIONAL\%2c\%20CASO\%20UNEM I-\%20F.pdf

Cárdenas Niño, L., Arciniegas Rodríguez, Y. C., \& Barrera Cárdenas, M. (2009). Modelo de intervención en clima organizacional. International Journal of Psychological Research, 2, 121-127.

Chagray Ameri, N. H., Yovera, S. E. R. Y., Neri Ayala, A. C., Maguiña Maza, R. M., \& Hidalgo Vasquez, Y. N. (2020). Clima organizacional y desempeño laboral, caso: Empresa lechera peruana. Revista Nacional de Administración, 11, Article No. e3297.

Chiang Vega, M. M., Salazar Botello, C. M., \& Núñez Partido, A. (2007). Clima Organizacional y Satisfacción Laboral en un Establecimiento de Salud Estatal: Hospital Tipo 1. Theoria, 16, 61-76.

Ehrhart, M. G., \& Schneider, B. (2016, diciembre 22). Organizational Climate and Culture. Oxford Research Encyclopedia of Psychology. https://doi.org/10.1093/acrefore/9780190236557.013.3

Ehrhart, M. G., Schneider, B., \& Macey, W. H. (2013). Organizational Climate and Culture: An Introduction to Theory, Research, and Practice. Routledge. https://doi.org/10.4324/9781315857664

Ganga, F., Piñones, M., \& Saavedra, L. (2015). Clima organizacional: Algunos basamentos históricos y conceptuales para la reflexión.

http://www.fcsh.espol.edu.ec/es/clima-organizacional-algunos-basamentos-hist\%C3\%B $\underline{3 \text { ricos-y-conceptuales-para-la-reflexi\%C3\%B3n-por-francisco }}$

García Solarte, M. (2009). Clima Organizacional y su Diagnóstico: Una aproximación Conceptual. Cuadernos de Administración, 25, 43.

Grueso, M., Ortega, J., \& Duque, E. (2016). Clima organizacional: Origen, evolución y medición. In Universidad del Rosario (Ed.), Organizaciones Saludables y procesos organizacionales e individuales: Comprensión y retos (pp. 163-203). Editorial Universidad de Rosario.

https://vlex.com.co/vid/clima-organizacional-origen-evolucion-691186917

Iglesias Armenteros, A. L., Torres Esperón, J. M., \& Mora Pérez, Y. (2020). Estudios de clima organizacional: Revisión integrativa. MediSur, 18, 1189-1197.

Iglesias Armenteros, A. L., Torres Esperón, J. M., \& Rodríguez Solís, F. (2018). Un acercamiento al clima organizacional. Revista Cubana de Enfermería, 34, Article No. 1. 
http://revenfermeria.sld.cu/index.php/enf/article/view/1257

Instituto Nacional de Estadística y Geografía (INEGI) (2014, enero 1). Directorio Nacional de Unidades Económicas. DENUE. Censos Económicos 2014; Instituto Nacional de Estadística y Geografía (INEGI).

https://www.inegi.org.mx/app/mapa/denue/default.aspx

Jaime Santana, P., \& Araujo Cabrera, Y. (2007). Clima y cultura organizacional: ¿dos constructos para explicar un mismo fenómeno? In Asociación Española de Dirección y Economía de la Empresa (AEDEM) (Ed.), Decisiones basadas en el conocimiento y en el papel social de la empresa: XX Congreso anual de AEDEM (Vol. 1, p. 19). Asociación Española de Dirección y Economía de la Empresa (AEDEM).

https://dialnet.unirioja.es/servlet/articulo?codigo $=2486886$

Jojoa Vargas, A. M. (2017). Importancia del Clima Organizacional en la Productividad Laboral. Master's Thesis, Universidad Militar Nueva Granada. https://repository.unimilitar.edu.co/bitstream/handle/10654/16749/JojoaVargas\%20An a\%20Milena2017.pdf;sequence $=1$

Méndez Álvarez, C. E. (2006). Clima organizacional en Colombia: El IMCOC, un método de análisis para su intervención (1. ed). Centro Editorial, Universidad del Rosario.

Minchan Portal, R. (2020). Relaciones interpersonales para mejorar el clima organizacional del Instituto de Educación Superior Tecnológico Público "Cajamarca”. Universidad Nacional Pedro Ruiz Gallo.

http://repositorio.unprg.edu.pe/handle/20.500.12893/8093

Morales Gaviria, M. A., \& Silva Mercado, M. M. (2012). Satisfacción laboral y clima organizacional: Análisis y relación desde una perspectiva teórica y empírica. Universidad Tecnológica de Bolívar.http://biblioteca.utb.edu.co/notas/tesis/0063892.pdf https://repositorio.utb.edu.co/handle/20.500.12585/991

Quintero, N., Africano, N., \& Faria, E. (2008). Clima Organizacional y Desempeño Laboral del Personal Empresa Vigilantes Asociados Costa Oriental del Lago. Negotium. Revista de ciencias gerenciales, No. 9, 33-51.

Robbins, S. P., Judge, T. A., \& Enríquez Brito, J. (2013). Comportamiento Organizacional. Pearson.

Rodríguez, E. (2016). El clima organizacional presente en una empresa de servicio. Revista Educación en Valores. Universidad de Carabobo, 1, 3-18.

Sagredo Pérez, M. (2013). Clima organizacional en la gestión del cambio para el desarrollo de la organización. Revista Cubana de Salud Pública, 39, 385-393.

Sánchez, O. R. (2017). Clima Organizacional en Siemens Enterprise S.A. Bachelor's Thesis, Universidad Galileo. http://biblioteca.galileo.edu/tesario/handle/123456789/613

Schneider, B., González-Romá, V., Ostroff, C., \& West, M. A. (2017). Organizational Climate and Culture: Reflections on the History of the Constructs in the Journal of Applied Psychology. The Journal of Applied Psychology, 102, 468-482.

https://doi.org/10.1037/apl0000090

Villanueva Galicia, S., García Oliver, M. F., \& Hernández Cruz, L. M. (2017). La importancia del clima organizacional, en la productividad de las empresas. TEPEXI Boletín Científico de la Escuela Superior Tepeji del Río, 4. 